J. Clin. Chem. Clin. Biochem.

Vol. 24, 1986, pp. 719-722

(C) 1986 Walter de Gruyter \& Co.

Berlin · New York

\title{
Immunoreactive Precipitation of C1 Inhibitor Protein from Plasma of Normal Subjects and of Patients with Hereditary Angioedema after Isoelectric Focusing
}

\author{
By L. Bergamaschini, C. Valle, M. Franzinelli, M. Cicardi and A. Agostoni \\ Department of Clinical Medicine, University of Milan, Milan, Italy
}

(Received March 5/June 2, 1986)

Summary: C1-inhibitor is an acid glycoprotein, isoelectric point 3.5-3.6. Plasma of some patients with a variant form of hereditary angioedema contains high levels of functionless C1-inhibitor-albumin complex with an isoelectric point at 4.5-4.6. Therapy with Danazol, which increases C1-inhibitor levels, does not modify the isoelectric focusing pattern of such protein in patients with hereditary angioedema.

Immunreaktive Fällung von C1-Inhibitor-Protein aus Plasma Gesunder und von Patienten mit hereditärem Angioödem nach isoelektrischer Fokussierung

Zusammenfassung: C1-Inhibitor ist ein saures Glykoprotein mit einem isoelektrischen Punkt von 3,5-3,6. Plasma bestimmter Patienten mit einer Variante des hereditären Angioödems enthält hohe Konzentrationen eines funktionslosen C1-Inhibitor-Albumin-Komplexes mit einem isoelektrischen Punkt von 4,5-4,6. Therapie mit Danazol, das die C1-Inhibitor-Konzentration erhöht, führt zu keiner Änderung des isoelektrischen Fokussierungsmusters dieses Proteins bei Patienten mit hereditärem Angioödem.

\section{Introduction}

The inhibitor of activated first component (C1-inhibitor) is the major regulatory factor for the classical pathway of activation of human complement $(1,2)$. It has also been shown to inhibit several enzymes of haemostasis: activated Hageman factor (Factor XII), Hageman factor fragment, kallikrein; activated thromboplastin antecedent (Factor XI) and plasmin $(3-6)$. Plasma from patients with hereditary angioedema was found to be deficient in $\mathrm{C} 1$-inhibitor function (inherited as an autosomal dominant trait), leading to the activation of complement. There are two forms of this disease. In the majority of the patients (type 1) there are very low levels of antigen concentration $(0.026-0.052 \mathrm{~g} / \mathrm{l})$. However $15-20 \%$ of the patients have the variant form with normal (type IIa) or elevated (type IIb) antigen concentration of a dysfunctional protein $(7-11)$. It has been demon- strated that in some hereditary angioedema patients with the variant form, both dysfunctional (94\%) and functional proteins $(6 \%)$ are present, and therapy with androgen derivatives increases both the proteins (12).

We have used isoelectric focusing to study C1-inhibitor in plasma from normal subjects and in patients with hereditary angioedema before and during androgen therapy, to determine the isoelectric point of the protein and evaluate the effects of such anabolic therapy on the characteristics of C1-inhibitor.

\section{Materials and Methods}

Normal and pathological specimens

Blood was drawn into plastic tubes containing $0.01 \mathrm{~mol} / \mathrm{l}$ EDTA. It was centrifuged within 1 hour, at $+4^{\circ} \mathrm{C}$, and sam- 
ples were stored in several aliquots at $-80^{\circ} \mathrm{C}$ until analysed. EDTA-plasma samples were taken from 10 healthy adult volunteers and from 18 hereditary angioedema patients:

10 with type I (C1-inhibitor antigen level: $0.026-0.052 \mathrm{~g} / \mathrm{l})$;

5 with type IIa (C1-inhibitor antigen level: $0.23-0.29 \mathrm{~g} / \mathrm{l})$ and 3 with type IIb (C1-inhibitor antigen level: $0.52-1 \mathrm{~g} / \mathrm{l})$.

$\mathrm{C} 1$-inhibitor functional activity was $10-20 \mathrm{U}$ in all 18 patients.

Samples from hereditary angioedema patients were obtained before and during therapy with $400 \mathrm{mg}$ /day Danazol for one month. At the sampling time, all the patients were asymptomatic.

Normal EDTA-plasmas were analysed after 2 hours and after storage for $2-4$ month at $-80^{\circ} \mathrm{C}$.

\section{Chemicals and antiserum}

Acrylamide, $\mathrm{N}^{\prime} \mathrm{N}^{\prime}$-methylenebisacrylamide and ampholines were obtained from SERVA-Feinbiochemica, Heidelberg (West Germany). The agarose (low-m $=0.13 \pm 0.02$ ) was a product of BIO-RAD Laboratories, Richmond Calif. (USA). Specific antisera against $\mathrm{C} 1$-inhibitor and albumin were obtained from Behringwerke, Marburg (West Germany).

Isoelectric focusing (IEF)-1ying on the immunoelectrophoresis matrix

Thin layer IEF was performed as described by Righetti (13) with the following modifications: $4.4 \%$ polyacrylamide gel was obtained from a stock solution of $30 \% \mathrm{~T} 4 \% \mathrm{C}$, and contained $1.3 \mathrm{~mol} / \mathrm{l}$ glycerol, 3.5\% Ampholine 3-10 and 2.5\% Ampholine 2-4; gels were polymerized on glass plates (U frame $1 \mathrm{~mm}$ ) with $2.6 \mathrm{mmol} / \mathrm{l}$ tetramethylethylendiamine and $1.7 \mathrm{mmol} / 1$ ammonium persulphate. The anolyte was $1.0 \mathrm{~mol} / \mathrm{l}$ phosphoric acid and the catholyte $1.0 \mathrm{~mol} / \mathrm{l}$ sodium hydroxide.

The samples $(18 \mu \mathrm{l})$ were applied to the cathode end side, in a well on the gel surface.

IEF were run on the LKB Multiphore apparatus, with a cooling system (temperature on the gel surface $+6-8^{\circ} \mathrm{C}$ ), for 4 hours, at $10 \mathrm{~W}$ constant power with voltage increasing from 300 to $1600 \mathrm{~V}$.

After completion of the isoelectric focusing run, the $\mathrm{pH}$ gradient was determined and strips were cut in the migration area. They were then placed on $0.9 \%$ agarose $-4 \%$ polyethyleneglycol gel plates containing monospecific antibody, and electrophoresis ( $3 \mathrm{~mA}$ for 12 hours) was performed. Tris/barbital buffer, ionic strengh $0.1, \mathrm{pH} 8.6$, was used for buffer vessels and gels. Agarose gel plates were stained with Coomassie Brillant Blue.

\section{C1-inhibitor plasma levels estimation}

The antigen level of $\mathrm{C} 1$-inhibitor was determined by single radial immunodiffusion on cellulose acetate strips (14); C1inhibitor functional activity was determined by its inhibition of C1-esterase activity towards $\mathrm{N}$-acetyl- $L$-tyrosine-ethyl ester (15).

\section{C1-inhibitor reference values}

C1-inhibitor antigen level (mean $\pm \mathrm{SD})=0.26 \pm 0.8 \mathrm{~g} / \mathrm{l}$

C1-inhibitor functional activity (mean $\pm \mathrm{SD}$ ) $=0.90 \pm 0.12 \mathrm{U}$ of C1-inhibitor

( $\mathrm{U}$ of $\mathrm{C} 1$-inhibitor $=$ activity of $1 \mathrm{ml}$ of fresh normal plasma)

\section{Results}

Plasma-EDTA samples from ten normal volunteers were studied by isoelectric focusing-immunoelectrophoresis after 24 hours and after 3-8 months storage at $-80^{\circ} \mathrm{C}$. In all samples, C1-inhibitor protein focused at $\mathrm{pH} 3.5-3.6$, giving only one peak in immunoelectrophoresis (fig. 1).

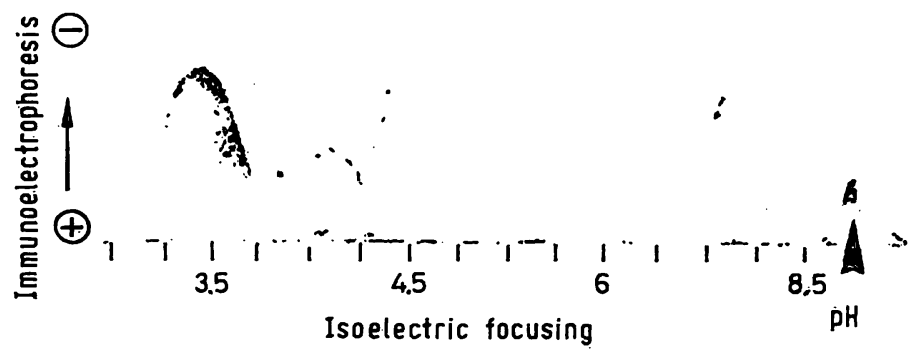

Fig. 1. Immunoelectrophoretic pattern after isoelectric focusing of C1-inhibitor protein in EDTA-plasma from a healthy subject.

Arrow indicates site of the sample application on the gel, before isoelectric focusing.

Plasma-EDTA samples from ten untreated patients with type I hereditary angioedema (C1-inhibitor antigen level less than $0.052 \mathrm{~g} / \mathrm{l}$ ) gave only one peak at $\mathrm{pH} 3.5-3.6$, as observed for normal subjects. The same patients were treated with Danazol for one month $(400 \mathrm{mg} /$ day). The antigen concentration of C1-inhibitor increased to $0.078-0.10 \mathrm{~g} / 1$ and functional activity to $35-45 \mathrm{U}$. There were no differences between C1-inhibitor in the plasma-EDTA before and during anabolic therapy (fig. 2).

Of the 8 patients with Type II hereditary angioedema; five (Type IIa) had C1-inhibitor antigen levels in the range $0.21-0.28 \mathrm{~g} / \mathrm{l}$ and three (Type IIb) in the range $0.52-1 \mathrm{~g} / \mathrm{l}$. After one month of therapy with Danazol (400 mg/day), antigen levels had increased about 2 times while functional activity still ranged from 35 to $40 \mathrm{U}$.

Plasma-EDTA of Type IIa patients gave only one peak at $\mathrm{pH} 3.5-3.6$, both before and during Danazol therapy (fig. 2).

In 3 untreated patients with Type IIb disease, plasmaEDTA exhibited a minor peak at $\mathrm{pH} 3.5-3.6$, but $80-90 \%$ of the reacting material focused at $\mathrm{pH} 4.5-$ 4.6 (fig. 3). This major peak could not be reproduced when crossed immunoelectrophoresis was performed with an intermediate gel containinguanti-albumin (fig. 4). Although the precision of the quantitative estimation is rather low with this method, Danazol therapy apparently increased equally the amounts of protein focusing at both isoelectric points. 


\section{Eppendorf -}

Diagnosticasysteme haben vieles gemeinsam -

angefangen vom Netzstecker bis hin zu unserem Knowhow auf dem Gebiet der Entwicklung und Fertigung hochwertiger Analysengerăte.

Ein für alle Einsatzgebiete in der klinischen Chemie gleichermaßen geeignetes Gerät zu entwickeln, ist auch uns noch nicht gelungen. Deshalb bieten wir verschiedene Systeme, zugeschnitten auf inre individuellen Bedürnnisse.

Für welches Eppendorf Analysensystem Sie sich auch entscheiden, unser bewährtes, auf das klinischchemische Labor spezialisierte Service- und Beratungsteam ist für alle da!

\section{Einer für alle?}

\section{EASY -}

sichere Ergebnisse rund um die Uhr.

Das EASY-System für Notfallanalysen und Kleinserien ist 24 Stunden am Tag einsatzbereit - bei minimalem Bedienungsaufwand. Die wichtigsten Enzym-, Substrat- und Elektrolytbestimmungen werden als gebrauchsfertige Küvettentests von Merck geliefert.

Nach Zuführung von Probe und EASY-Test-Küvetten arbeitet das System völlig selbstăndig, schnell und zuverlässig.

\section{EPOS -}

für Routine und Spezialverfahren.

Das selektive Analysensystem EPOS ${ }^{\circledR}$ - ideale Kombination von Analysengerät und Microcomputer - ist problemlos in jede Labororganisation zu integrieren. Neben üblichen RoutineVerfahren sind bei hohem Durchsatz auch Spezialverfahren, z.B. EMIT ${ }^{\circledR}$ möglich. Variable Methodenparameter, stationäre Küvetten und geringe Reagenzvolumina sind weitere Faktoren für flexiblen und wirtschaftlichen Betrieb.

\section{ERIS ${ }^{\circ}$ -}

das schnelle System für Ihre Routine-Methoden.

Mit ERIS ${ }^{\circ}$ bestimmen Sie bis zu 23 Parameter selektiv aus einer Probe - als Einzelbestimmung oder als Profil schnell und sicher. Notfallproben? Kein Problem! Bereits nach 10-15 Minuten liegt das Resultat für alle angeforderten Tests vor - bei unverändert hohem

Analysen-Durchsatz. Die von Merck entwickelten ERIS -

Tests sind speziell auf die Erfordernisse des Systems abgestimmt.

\section{Bitte rufen Sie uns an,}

wir diskutieren mit Ihnen die optimale Lösung für Ihr Labor.

Eppendorf Gerätebau Netheler + Hinz GmbH Postfach 650670 2000 Hamburg 65 Telefon (040) 53801-0 Telex $2174315 d$ 


\section{DELTA EF 500 FILTERPHOTOMETER}

Ein DELTA EF 500 Präzisionsphotometer aus dem "economic program" von DELTA ELEKTRA ist die ideale Hilfe für Messungen im Routinelaboratorium.

Dafür sorgen funktioneller Aufbau, moderne Elektronik, Digitalanzeige von Absorbance und vier Konzentrationen, automatische Nullpunktkompensation, genaue Linearität und Reproduzierbarkeit. Für größere Serien verfügt das DELTA EF 500 über eine Absaugküvette und eingebaute Pumpe sowie analoges Ausgangssignal.

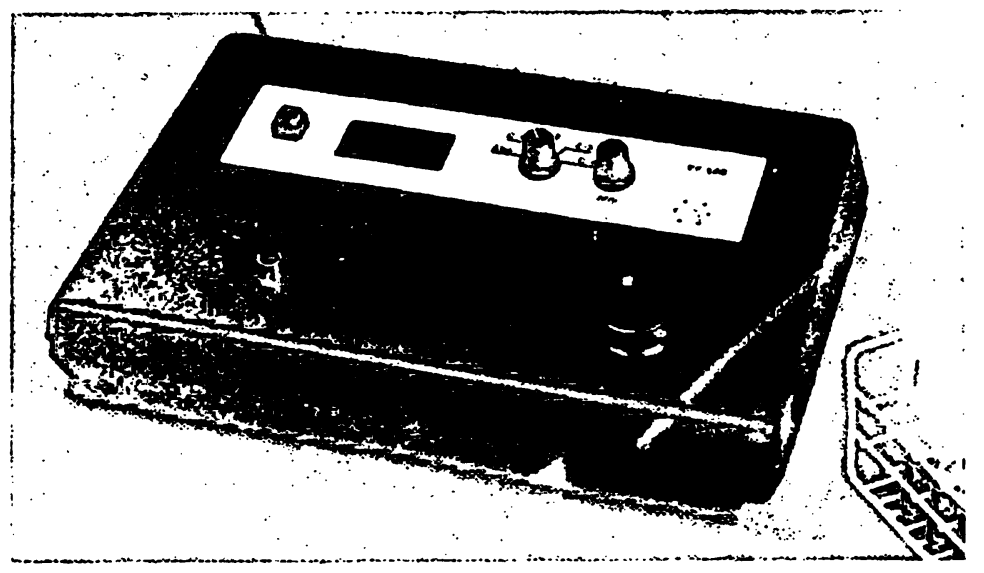

DELTA ELEKTRA

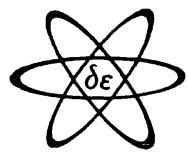

Ihr Laborpartner aus Holland
Information verschaffen der Hersteller und Ihr Fachhändler. Verlañgen Sie eine Vorführung, denn das DELTA EF 500 bedeutet einen Durchbruch im Produkt/Preis Verhältnis.

DELTA ELEKTRA B. V. - Rijksweg 29 - NL - 7975 RT Uffelte
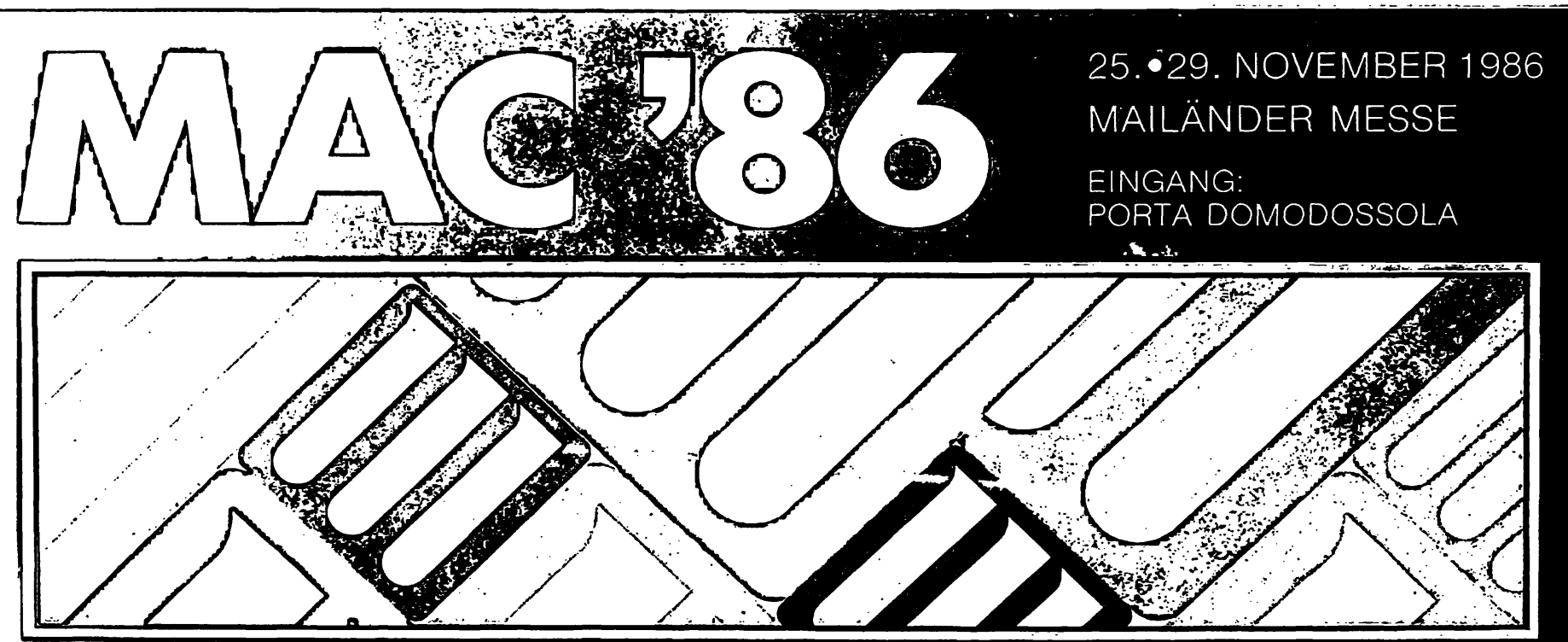

26, INUIERNATIONALE FACHMESSE FÜR CHEMISCHE APPARATE, WANAIYSEN - FORSCHUNGS - PRÜFGERÄTE UND BIOTECHNOLOGIEN
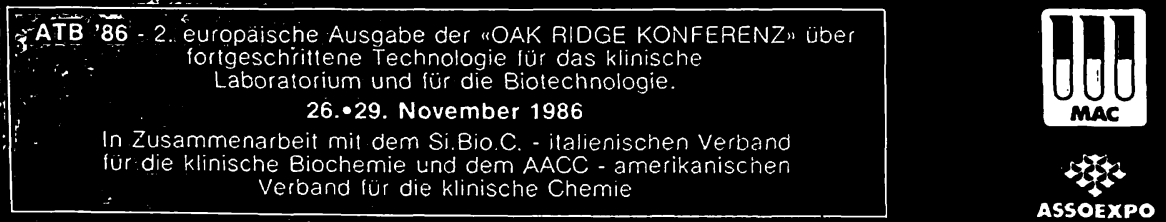

Nur den Fachleuten reserviert Öffnungszeiten: von 9.00 bis 18.00 Uhr Generalsekretariat MAC: Via Domenichino, 11 20149 Mailand (Italien) Tel.: (02) 4815541 


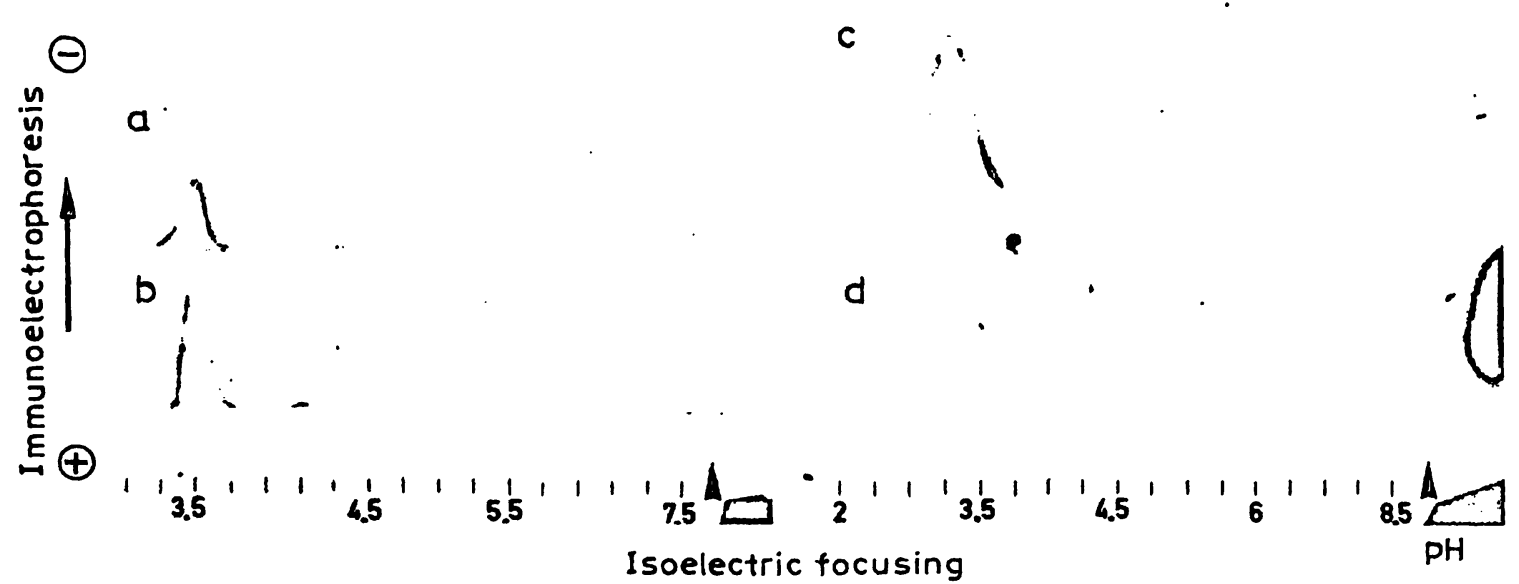

Fig. 2. Effects of Danazol therapy on C1-inhibitor in EDTA-plasma from patients with hereditary angioedema: Type $\mathrm{I}=\mathrm{a}$, b; Type IIa $=c$, d.

$\mathrm{a}=$ pretreatment sample, $\mathrm{C} 1$-inhibitor antigen level $=0.04 \mathrm{~g} / \mathrm{l}$

$\mathrm{b}=$ one month of therapy, C1-inhibitor antigen level $=0.09 \mathrm{~g} / 1$

$\mathrm{c}=$ pretreatment sample, C1-inhibitor antigen level $=0.24 \mathrm{~g} / 1$

$\mathrm{d}=$ one month therapy, C1-inhibitor antigen level $=0.46 \mathrm{~g} / \mathrm{l}$

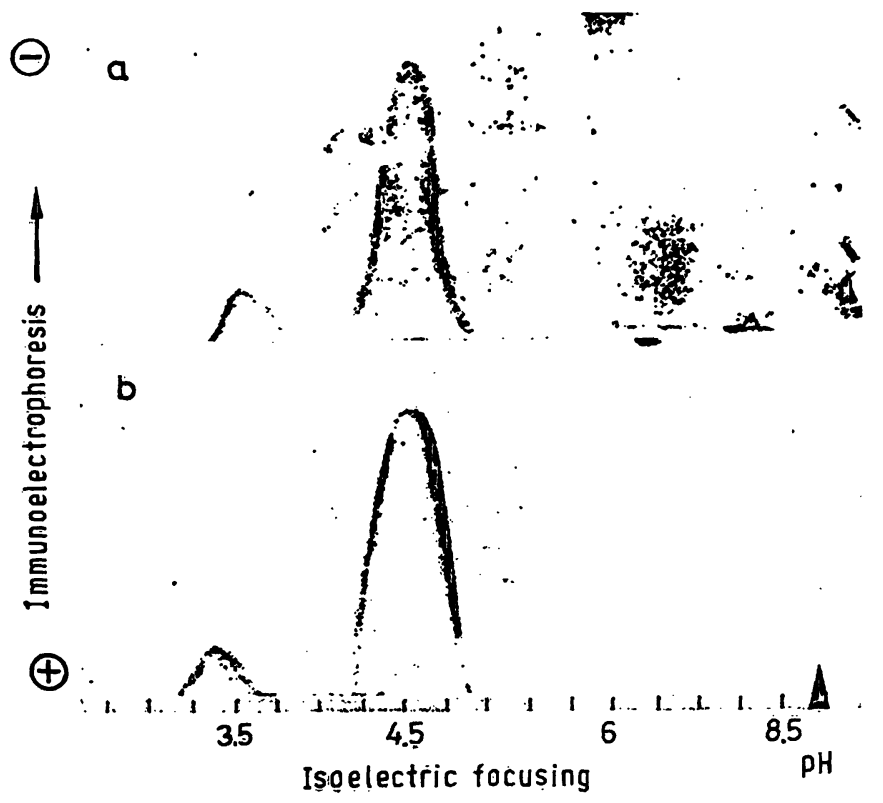

Fig. 3. Effects of Danazol therapy on C1-inhibitor in EDTAplasma from a patient with Type IIb hereditary angioedema with a high C1-inhibitor antigen level.

$a=$ pretreatment samples, $C 1$-inhibitor antigen level

$=0.62 \mathrm{~g} / \mathrm{l}$ (sample dilution $1: 2$ )

$\mathrm{b}=$ one month treatment, $\mathrm{C} 1$-inhibitor antigen level $=1.2 \mathrm{~g} / 1$ (sample dilution $1: 4)$

\section{Discussion}

From this study we conclude that $\mathrm{C1}$-inhibitor is a very acidic protein, with an isoelectric point of $3.5-$ 3.6, which is intermediate between those previously reported by Haupt (16) and Curd (12). The charge on the protein did not change during storage at $-80^{\circ} \mathrm{C}$ for 8 months. All our patients with hereditary angioedema had normal $\mathrm{C} 1$-inhibitor at $\mathrm{pH} 3.5-$ 3.6. In type IIa, with normal antigenic levels of C1inhibitor, we could not differentiate functionless protein from normal $\mathrm{C} 1$-inhibitor.

In 3 patients (type IIb) with $\mathrm{C} 1$-inhibitor antigen levels 2-4 times the normal value, the majority of antigenic material was focused at $\mathrm{pH} 4.5-4.6$ and immunoprecipitated both with anti-C1-inhibitor and anti-albumin, suggesting the presence in the plasma of a functionless complex $\mathrm{C} 1$-inhibitor-albumin as previously reported (17). In all 3 patients, the C1inhibitor in pretreatment plasma was indistinguishable from the $\mathrm{C} 1$-inhibitor obtained during Danazol treatment, which increased the synthesis of both the dysfunctional $\mathrm{C} 1$-inhibitor and normal $\mathrm{C} 1$-inhibitor gene products.

The fact that in type IIa disease both normal and functionless protein have the same charge confirms that the chemical difference responsible for the dysfunction must be very small (probably a few amino acid substitutions), since it does not cause any detectable change in size or antigenicity.

\section{Acknowledgement}

We thank Dr. P. G. Righetti for his helpful comments and assistance.

This work was supported by a grant of the "Special Project on Genetical Engineering and Molecular Basis of Hereditary Diseases" of C.N.R., Rome, Contract No. 83.00700.51. 


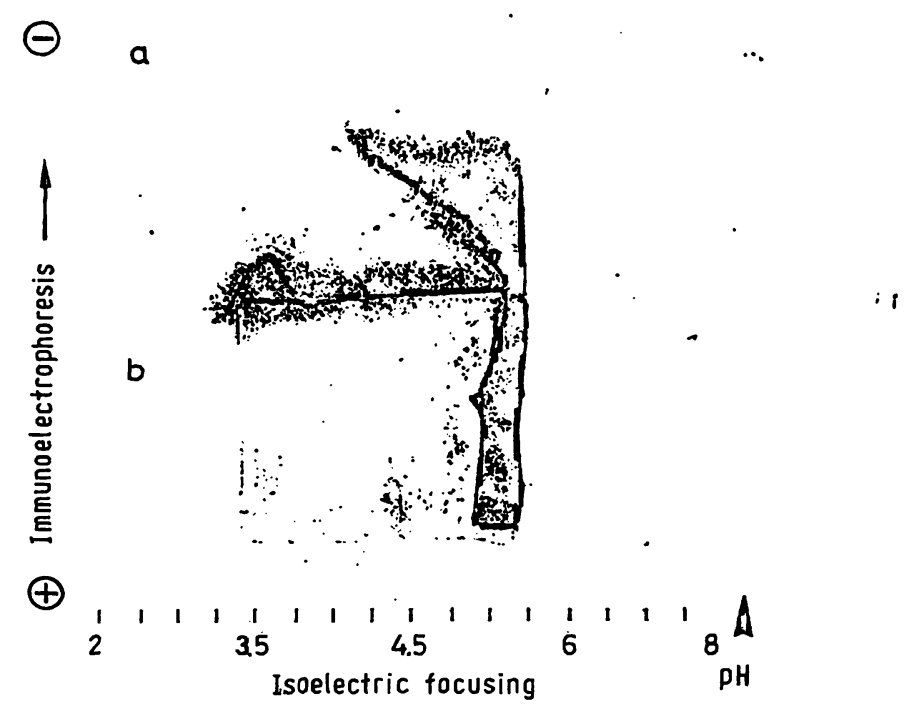

Fig. 4. Disappearance of the major peak focused at $\mathrm{pH} 4.5-4.6$ in plasma from a patient with type IIb hereditary angioedema in an anti-albumin intermediate gel.

a: gel containing anti-albumin antibody

b: gel containing anti-C1-inhibitor antibody

\section{References}

1. Levy, J. R. \& Lepow, I. H. (1959) Proc. Soc. Exp. Biol. Med. 101, 608-611.

2. Gigli, I., Ruddy, S. \& Austen, K. F. (1968) J. Immunol. 100, 1154-1164.

3. Ratnoff, O. D., Pensky, J., Ogston, D. \& Naff, G. B. (1969) J. Exp. Med. 129, 315-331.

4. Forbes, C. D., Pensky, J. \& Ratnoff, O. D. (1970) J. Lab. Clin. Med. 76, 809-815.

5. Schreiber, A. D., Kaplan, A. P. \& Austen, K. F. (1973) J. Clin. Invest. 52, 1402-1409.

6. Donaldson, H. D. \& Harrison, R. A. (1982) Blood 62, $121-129$.

7. Rosen, F. S., Charache, P., Pensky, J. \& Donaldson, V. H. (1965) Science 148, 957-958.

8. Donaldson, V. H. \& Evans, R. R. (1983) Am. J. Med. 35, $37-44$.

9. Rosen, F. S., Alper, C. A., Pensky, J., Kemperer, M. B. \& Donaldson, V. H. (1971) J. Clin. Invest. 50, 2143-2149.

10. Donaldson, V. H., Harrison, R. A., Rosen, F. S., David, H. B., Kindness, G., Canar, J., Wagner, C. J. \& Awad, S. (1985) J. Clin. Invest 75, 124-132.
11. Cicardi, M., Bergamaschini, L., Marasini, B., Boccassini, G., Tucci, A. \& Agostoni, A. (1982) Am. J. Med. Sci. 284, 2-9.

12. Curd, J. G., Yelvington, M., Ziccardi, R. J., Mathison, D. A. \& Griffin, J. H. (1981) Clin. Exp. Immunol. 45, 261270.

13. Righetti, P. G. (1983) In: "Isoelectric focusing: theory, methodology and applications. Laboratory techniques in biochemistry and molecular biology", (Wor, T. S. \& Burdon, R. H., eds.) Elsevier Biomedica Press/Amsterdam, New York, Oxford.

14. Agostoni, A., Stabilini, R. \& Vergani, C. (1970) Progr. Immunobiol. Standard 4, 149 $=151$.

15. Lachmann, P. J., Hobart, M. J. \& Aston, W. P. (1973) Complement technology, In: "Handbook of experimental immunology" (Weir, D. M., ed.) Oxford: Balckwell.

16. Haupt, H., Heimburger, N., Kranz, T. \& Schwick, H. G. (1970) Eur. J. Biochem. 17, 254-261.

17. Laurell, A. B. \& Martensson, U. (1971) Eur. J. Immunol $1,146-149$.

\author{
Dr. Luigi Bergamaschini \\ Clinica Medica V \\ Ospedale S. Paolo \\ Via di Rudini 8 \\ I-20142 Milano
}

